\title{
EDITORIAL O rosto sereno e calmo da tolerância
}

Na pequena praça, atrás do Institut de France, em Paris, a face do filósofo permaneceu serena e impassível face à intolerância que lhe trouxera novo matiz. Relativizado, o vermelho da tinta que escorreu pelo rosto da estátua poderia simplesmente reduzir-se a um ato de vandalismo, não representasse ela Voltaire e o feito, mimetizado, traduzisse muito do que ele disse em vida. Falamos, é claro, da [in]tolerância, palimpsesto sobre o qual se desenha muito do discurso social.

Em 1752, Voltaire escreve seu Poème sur la loi naturelle. Nele, ao explicitar as bases de sua concepção de um mundo querido por Deus e das relações deste para com os homens, o filósofo afirma que as religiões humanas desfiguram a religião natural, provocando o fanatismo, as divisões e as guerras, imprimindo à [in]tolerância uma essência religiosa. Não por outra razão, hora ou outra, Voltaire se vê às voltas com a intolerância: em 1994, por exemplo, o diretor de teatro Hervé Loichemol, ao encenar Mahomet, teve as subvenções ao espetáculo retiradas pela cidade de Genebra sob o pretexto de não "ferir" a susceptibilidade da comunidade muçulmana; as mesmas pressões reapareceram em 2005, em Saint-Genis, na França, quando de uma leitura da mesma peça.

Por essas e outras razões cabe a pergunta: por que estudar o século XVIII francês hoje? Entre outros motivos, não só porque os debates, as tensões e as angústias que tumultuavam os espíritos setecentistas continuam vivos e ululantes, mas sobretudo, porque a intolerância ora se traveste de um discurso humanista, ora chega às vias de fato. 
Lembremos, por exemplo, do recente 7 de janeiro de 2015, quando dois homens invadem a sede do jornal satírico Charlie Hebdo, em Paris, e dispararam contra cidadãos sob pretexto religioso. Nessa manhã, os cartunistas Charbonnier (diretor do semanário e alvo principal dos terroristas), Honoré, Tignous, Wolinsk e Cabu viram a noite em razão de terem respondido pacificamente à violência e à barbárie. Na Rue de Seine, o rosto do filósofo continuara imperturbável, porém, nos dias que se seguiram à tragédia, sua figura avultou-se espontaneamente, sendo recolocada como o inimigo número um do fanatismo.

O número 6 da Non Plus, que traz um dossiê dedicado ao Século XVIII francês, convida o leitor a refletir sobre muitas das inquietações que povoaram as mentes setecentistas e que, teimosamente, insistem em desconcertar nosso quotidiano, obrigando-nos a certo passéisme, na tentativa de compreendermos muito das questões atuais.

Assim, nessa toada, trazemos ao leitor três textos apresentados como trabalho de conclusão ao curso monográfico "Tradition et subversion chez Voltaire" ministrado pela então pós-doutoranda do programa e bolsista da CAPES, Ana Luiza Reis Bedê ${ }^{1}$, sob a coordenação da Profa. Verónica Galindez Jorge, no segundo semestre de 2014, na FFLCH-USP.

O artigo de Márcia Rigonatto discute o humor voltairiano no conto Micromégas a partir de noções apresentadas por Henri Bergson em seu Le Rire. Andrei Fernando Lima Silva aborda a questão da felicidade em Candide ou l'Optimisme procurando compreender essa noção no texto de Voltaire e no amplo contexto da história das ideias. Há ainda a instigante relação feita por Márcia Valéria Martinez de Aguiar entre o Traité sur la tolérance (1763), de Voltaire, e Douze hommes en colère (1957), filme de Sidney Lumet. Mais uma vez a contemporaneidade de Voltaire vem à tona por meio de discussões jurídicas, tão caras ao autor em seus últimos anos de vida.

Se o século XVIII representou momento privilegiado na luta contra a superstição e a tirania da Igreja, também foi palco de debates acirrados em torno da questão da liberdade. Ideias ousadas, muitas vezes mal compreendidas e que marchavam na contramão do ideal das Luzes, vieram do nobre prisioneiro Alphonse Donatien François de Sade - le grand Marquis. Em seu país de origem, à obra do autor de La Philosophie dans le boudoir (1795) coube certo ostracismo até que, em meados do século XX, críticos de diferentes orientações se debruçaram sobre a complexidade de suas ideias.

Assim, leitor, razão melhor não havia para que não inaugurássemos nossa seção de entrevista falando desses e outros temas em torno de Marquês de Sade com a professora e ensaísta Eliane Robert Moraes, em elucidativa e densa entrevista concedida à Non Plus.

${ }^{1}$ Pós-doutoranda Université Paris IV-Sorbonne (Ministère de l’Éducation nationale du Brésil - CAPES). 
Também sobre o Marquês, Clara Carnicero de Castro brinda-nos com o artigo "Juliette, l'anti-Julie? Sade rousseauiste", em que esmiúça as semelhanças entre a heroína de Julie ou la Nouvelle Héloïse (1761) de Rousseau e a libertina de Histoire de Juliette (1801), de Sade.

Camila Sant'Ana Vieira Ferraz Milek debruça-se sobre o tema "A noção de felicidade em Helvétius: a virtude bem comportada”. Helvétius, a despeito de sua importância nos grandes debates do Século das Luzes, continua autor pouco conhecido no Brasil. Ressaltamos o estudo de Jean-Christophe Abramovici sobre Marivaux e a libertinagem estética de seu discurso. Professor de Literatura Comparada da Université Paris IV-Sorbonne, Abramovici, enriquece a Revista com "Penser en hommes: le sourire du spectateur de la cinquième feuille".

Completando o dossiê sobre o século XVIII e na esteira dos estudos de relação Brasil-França, Dayane Mussulini, em seu "A intertextualidade em Ernesto de Tal: a presença de Le Barbier de Séville como memória da literatura", tece uma relação entre o clássico de Beaumarchais e a narrativa "Ernesto de Tal", de Machado de Assis e publicada em 1873 .

De fato, a área de literatura francesa da USP vem, nos últimos anos, publicando trabalhos expressivos no âmbito dos estudos de fonte e de intertexto. Destaca-se, nesse âmbito, o Prof. Gilberto Pinheiro Passos, pesquisador dessa perspectiva de análise, e que assina a resenha "As visões desencantadas" sobre a tese "Humanismo satírico em Lima Barreto e Anatole France”, de Milene Suzano de Almeida.

Em seu espaço aberto, diferentes autores e perspectivas críticas são contemplados: "Rabelais antropofágico: banqueteando os novos tempos", de Meriele Miranda de Souza; "O espaço de criação do pintor nas obras de Balzac: um passeio pelos ateliês de Porbus, Servin e Grassou”, de Izabela Baptista do Lago, "Le Dernier Mot, de Maurice Blanchot, ou a torre de babel", de Davi Andrade Pimentel e "Pesquisa em fontes primárias: a obra romanesca de Jules Verne, entre literatura e projeto editorial", de Edmar Guirra dos Santos.

A você, leitor, inquietações setecentistas e uma boa leitura!

Ana Luiza Reis BEDÊ Dirceu MAGRI Editores 